\section{Short-duration Water Stress Decreases Onion Single Centers without Causing Translucent Scale}

\author{
Clinton C. Shock, Erik B.G. Feibert ${ }^{1}$, and Lamont D. Saunders \\ Oregon State University, Malheur Experiment Station, 595 Onion Avenue, \\ Ontario, OR 97914
}

Additional index words. soil water tension, drip irrigation

\begin{abstract}
Single centeredness has become an important onion attribute for marketing because of the use of onions in food products such as onion rings. Although onion single centeredness is largely cultivar dependent, it may also be influenced by growing conditions. These trials tested the effects of early-season, short-duration water stress on onion single centeredness. The effects of the short-duration water stress were also evaluated on onion yield, grade, and translucent scale. Translucent scale is a physiological disorder thought to be influenced by water stress. Onions were drip irrigated automatically at a soil water tension (SWT) of $20 \mathrm{kPa}$ and were submitted to shortduration water stress in 2003, 2004, and 2005. Onions in each treatment were stressed once at either the two-leaf, four-leaf, early six-leaf, late six-leaf, or eight-leaf stage and were compared with a minimally stressed control. Onions were stressed by interrupting irrigations until the SWT at a $0.2-\mathrm{m}$ depth reached $60 \mathrm{kPa}$, at which time the irrigations were resumed. Onion single centeredness was reduced by short-duration water stress in 2003 and 2005. Onions were sensitive to the formation of multiple centers with water stress at the four-leaf to late six-leaf stages. The $\mathbf{2 0 0 4}$ growing season was characterized by cool, moist conditions, and water stress did not affect single centeredness. Among all treatments and years, marketable yield was only reduced in 2005 , with stress at the four-leaf and eight-leaf stages. The incidence of translucent scale was very low each year and was not related to early-season water stress.
\end{abstract}

Frequent irrigations to maintain high soil moisture are required to produce high yields of onion (Allium cepa L.) (Al-Jammal et al., 2000; Bucks et al., 1981; Chung, 1989; de Santa Olalla et al., 1994; Ells et al., 1993; Hegde, 1986; Jones and Johnson, 1958; Kadayifci et al., 2005; Koriem et al., 1994; Nassar and Waly, 1977; Rana and Sharma, 1994; Shock et al., 1998b, 2000a). Although irrigation criteria vary between locations and situations, we found that drip-irrigated onion grown in the Treasure Valley of eastern Oregon should be irrigated at a soil water tension (SWT) of $20 \mathrm{kPa}$ (Shock et al., 2000a).

Both onion yield and size have also been found to be reduced by temporary imposed water stress. Jones and Johnson (1958) found that withholding irrigations for 2 weeks in any of three periods during the season resulted in yield reductions. Van Eeden and Myburgh (1971) irrigated onion at $60 \%$ of the available soil water and found that yield was reduced when the soil moisture depletion was allowed to reach $90 \%$ of the available water during the second half of the season. Using rain shelters, Dragland (1974) showed that onion yield

Received for publication 2 Feb. 2007. Accepted for publication 29 Mar. 2007.

${ }^{1}$ To whom reprint requests should be addressed; e-mail erik.feibert@oregonstate.edu bulbs (Brewster, 1994). Environmental and management factors may influence onion single centeredness by inducing axillary branching. Short interruptions of irrigation, resulting from the need to perform tractor operations in furrow-irrigated onion or from system failures with drip irrigation, might reduce onion single centeredness under commercial production conditions. In a 3-year study with drip-irrigated onions in the Columbia Basin of Washington, Pelter et al. (2004) showed that temporary water stress might be related to reduced single centeredness. Single water stress episodes were imposed and the SWT was allowed to rise from 30 to $70 \mathrm{kPa}$ and then was brought back to $30 \mathrm{kPa}$ in 1999,2000 , and 2002 . However, because of delays in reirrigating at the end of the stress episodes, some of the treatments resulted in more intense and longer stress than planned, leaving in doubt the effect of short-term water stress on onion single centeredness.

Translucent scale is an internal bulb defect in which one or more rings or scales acquire a translucent or watery appearance, rendering the onion unmarketable. Werner and Harris (1965) found that high air and soil temperatures during the growing season induced translucent scale. Higher soil and air temperatures might be induced by an interruption of irrigation and the resulting lack of evaporative cooling by the soil and plant leaves.

This trial tested the effect of a single episode of water stress at different early onion growth stages on bulb single centeredness, translucent scale, yield, and grade.

ductions were more pronounced with 3 weeks of water stress at the beginning of the season than in the middle or end of the season. Irrigating onion at a higher soil water tension of 30,50 , or $70 \mathrm{kPa}$ during the last 5 weeks of the season compared with $20 \mathrm{kPa}$ reduced yield and size (Shock et al., 2000b). Sorensen and Grevsen (2001) found that drought stress during the last 3 weeks of the season reduced onion yields. None of these water stress studies measured onion single centeredness.

Onion single centeredness is an important characteristic for the food industry. Onion ring manufacturing efficiency is reduced when onions are multiple centered. Onion ring manufacturers have a target of $85 \%$ of the bulbs being either single centered or having a multiple center no larger than 3.8 $\mathrm{cm}$ diameter ("functionally single centered"). Food companies that contract with onion growers typically require $75 \%$ of the bulbs be functionally single centered, with incentives for higher percentages. Single centeredness is to some extent a cultivar attribute (Shock et al., 2005) and is a heritable onion trait that allows for the development of cultivars with a high degree of single centers (Cramer, 2006; Gamie et al., 1995; Wall et al., 1996).

Axillary branching in onion, which occurs when a new lateral growing point forms adjacent to the existing one, leads to multiple growing points resulting in multiple-centered

\section{Materials and Methods}

The trials were conducted in 2003, 2004, and 2005 at the Malheur Expt. Sta., Ontario, OR, on Owyhee silt loam (coarsesilty, mixed, mesic, Xerollic Camborthid) previously planted to wheat (Triticum aestivum L.). In the fall preceding the trials, the fields were plowed, roller harrowed twice, fumigated with dichloropropene and chloropicrin (77.9\% 1,3-dichloropropene + $16.5 \%$ chloropicrin, Telone C-17; Dow Agrosciences, Indianapolis) at $225 \mathrm{~L} \cdot \mathrm{ha}^{-1}$, and bedded. Onions (cv. Vaquero, Nunhems, Parma, ID) were planted in two double rows per $1.1-\mathrm{m}$ bed on 17 Mar. each year. The onion double rows were spaced $0.56 \mathrm{~m}$ apart. Each double row consisted of two onion rows spaced $6 \mathrm{~cm}$ apart. Onions were planted at 370,000 seeds/ha. One drip tape (T-tape; TSystems International, San Diego) was installed at a $13-\mathrm{cm}$ depth in each bed between the two double rows. The drip tape had emitters spaced $30 \mathrm{~cm}$ apart and an emitter flow rate of $0.55 \mathrm{~L} \cdot \mathrm{h}^{-1}$. The field was sprinkler irrigated until seedling emergence. Onion emergence started on $7 \mathrm{Apr}$., 2 Apr., and 17 Apr. in 2003, 2004, and 2005 respectively.

The experimental design had five irrigation treatments in 2003 and six irrigation 
treatments in 2004 and 2005, arranged in randomized, complete block designs with five replicates. The drip-irrigated treatments consisted of a minimally stressed control and four timings of short-duration water stress in 2003 and five timings in 2004 and 2005. Each irrigation treatment plot was four double rows wide $(2.2 \mathrm{~m})$ by $15.3 \mathrm{~m}$ long. Each plot had a ball valve allowing manual control of irrigations. The water stress was applied by turning the water off manually to all plots in a given treatment until the average soil water tension at a $0.2-\mathrm{m}$ depth for that treatment reached $60 \mathrm{kPa}$. At this point, the irrigation to all plots in that treatment was turned on again. Upon termination of the stress for a treatment, all plots in that treatment were irrigated manually to equilibrate the soil moisture with the unstressed control treatment. Except for the unstressed control treatment, the onions in each treatment were stressed only once during the season. The five growth stages for the stress treatments were two-leaf (2004 and 2005 only), four-leaf, early six-leaf, late six-leaf, and eight-leaf. Onion growth stages were determined by counting the number of leaves on plants in every replicate. When $80 \%$ of the plants had a new leaf of the target growth stage that was about half the size of the next older leaf, the stress treatment was imposed. For the early six-leaf and late sixleaf stages, the target leaf was less than and more than half the size of the next older leaf respectively.

All plots, except those being stressed, were irrigated concurrently and uniformly. The irrigations were automatically controlled by a datalogger (CR10; Campbell Scientific, Logan, UT) using a relay driver (A21 REL, Campbell Scientific) connected to a solenoid valve. Irrigation decisions were made every $12 \mathrm{~h}$ by the datalogger as follows: If the average SWT at the $0.2-\mathrm{m}$ depth in the unstressed treatment plots was $20 \mathrm{kPa}$ (Shock et al., 2000a) or more, the field was irrigated for $4 \mathrm{~h}$ applying $6.1 \mathrm{~mm}$ of water. If the SWT was less than $20 \mathrm{kPa}$, the field was not irrigated. Soil water tension was measured in each plot with four granular matrix sensors (GMS; Watermark Soil Moisture Sensors model 200SS; Irrometer Co., Riverside, CA) installed at a $0.2-\mathrm{m}$ depth in the center of the double row. Sensors had been previously calibrated to SWT (Shock, 2003; Shock et al., 1998a). The GMS were connected to the datalogger using three multiplexers (AM 410 multiplexer, Campbell Scientific). The datalogger read the sensors and recorded the SWT every hour. The pressure in the drip lines was maintained at 70 $\mathrm{kPa}$ by a pressure regulator. Irrigations ended on 2 Sept. in 2003 and 2004, and on 5 Sept. in 2005.

The onions were lifted to cure on 11 Sept., 9 Sept., and 12 Sept. in 2003, 2004, and 2005 respectively. One week after lifting, the onions in the central $12.2 \mathrm{~m}$ of the middle two double rows $(1.1 \mathrm{~m})$ in each plot were topped, bagged, and placed into storage. The storage shed was managed to maintain air temperature as close as possible to $1^{\circ} \mathrm{C}$.

For the data to be representative of the local marketing conditions, the onions were stored for $\approx 2$ months before grading each year. Growers market onions directly from the field and after up to 7 months of storage. The onions were graded in early December each year. Bulbs were separated according to quality: bulbs without blemishes (no. 1s), split bulbs (no. 2s), and diseased bulbs. The no. 1 bulbs were graded according to diameter: small, $<5.7 \mathrm{~cm}$; medium, 5.7 to $7.6 \mathrm{~cm}$; jumbo, 7.6 to $10.2 \mathrm{~cm}$; colossal, 10.2 to 10.8 $\mathrm{cm}$; and supercolossal, $>10.8 \mathrm{~cm}$. Marketable onions were considered perfect bulbs in the medium, jumbo, colossal, and supercolossal size classes.

After grading, 50 bulbs ranging in diameter from 8.9 to $10.8 \mathrm{~cm}$ from each plot were rated for single centers and translucent scale. The onions were cut equatorially through the bulb middle and, if multiple centered, the long axis of the internal diameter of the first single ring was measured. These multiplecentered onions were ranked according to the diameter of the first single ring: "Small doubles" were defined to have diameters less than $3.8 \mathrm{~cm}$, "intermediate doubles" to have diameters from 3.8 to $5.7 \mathrm{~cm}$, and "large doubles" to have diameters greater than 5.7 $\mathrm{cm}$. Onions were considered functionally single centered for processing if they were single centered or a small double. The number and location of translucent scales in each bulb were also recorded.

The data were subjected to the general linear model analysis of variance procedure of NCSS statistical software (NCSS, Kaysville, UT). Treatment means were compared using Fisher's protected LSD at the 5\% probability level, LSD (0.05).

\section{Results}

Each year the average SWT during some of the stress treatments reached values
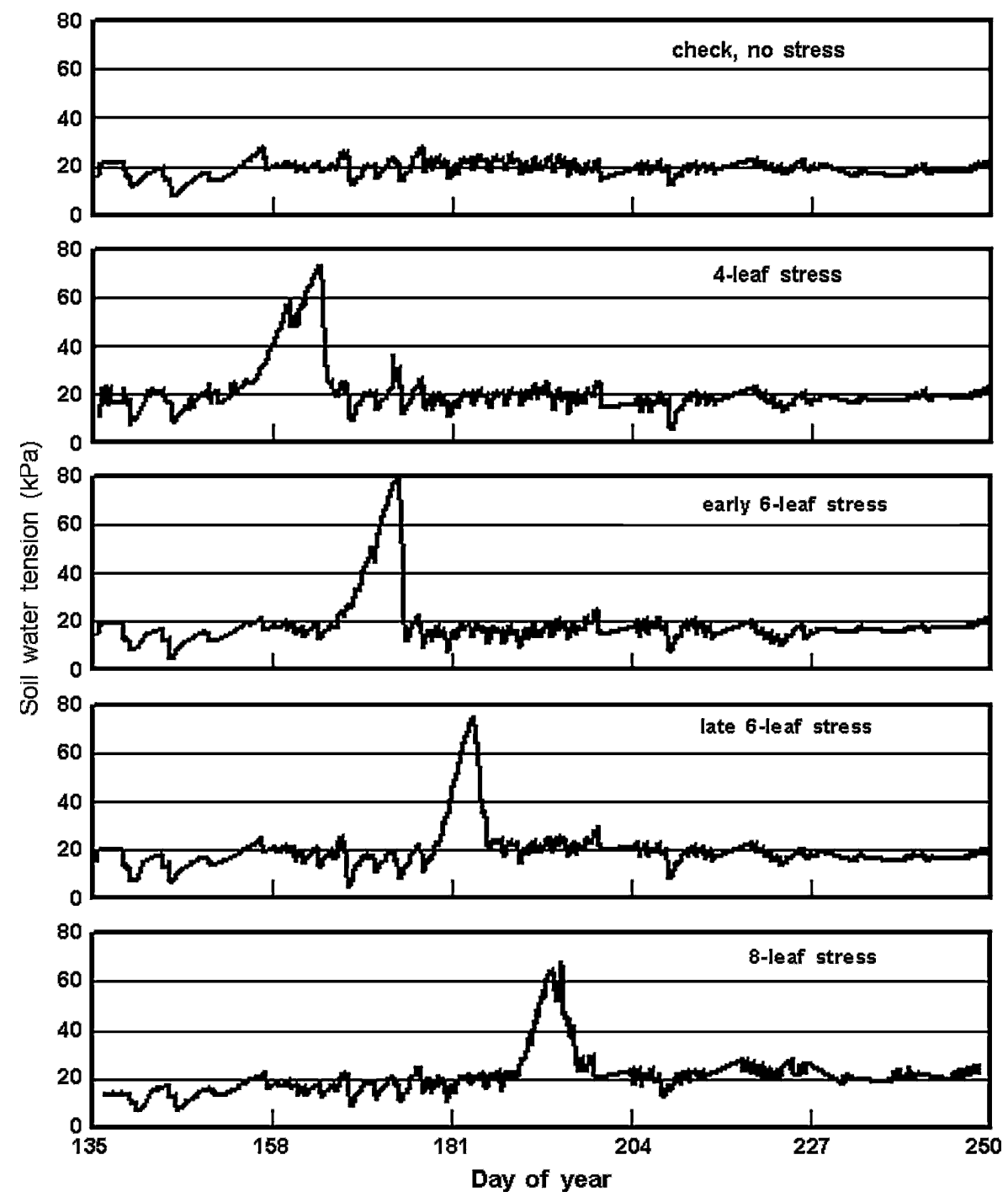

Fig. 1. Soil water tension for onions irrigated at $20 \mathrm{kPa}$ with an automated drip irrigation system and submitted to short-duration water stress in 2003. Data are the average of 20 sensors (four sensors per plot and five replicates). 

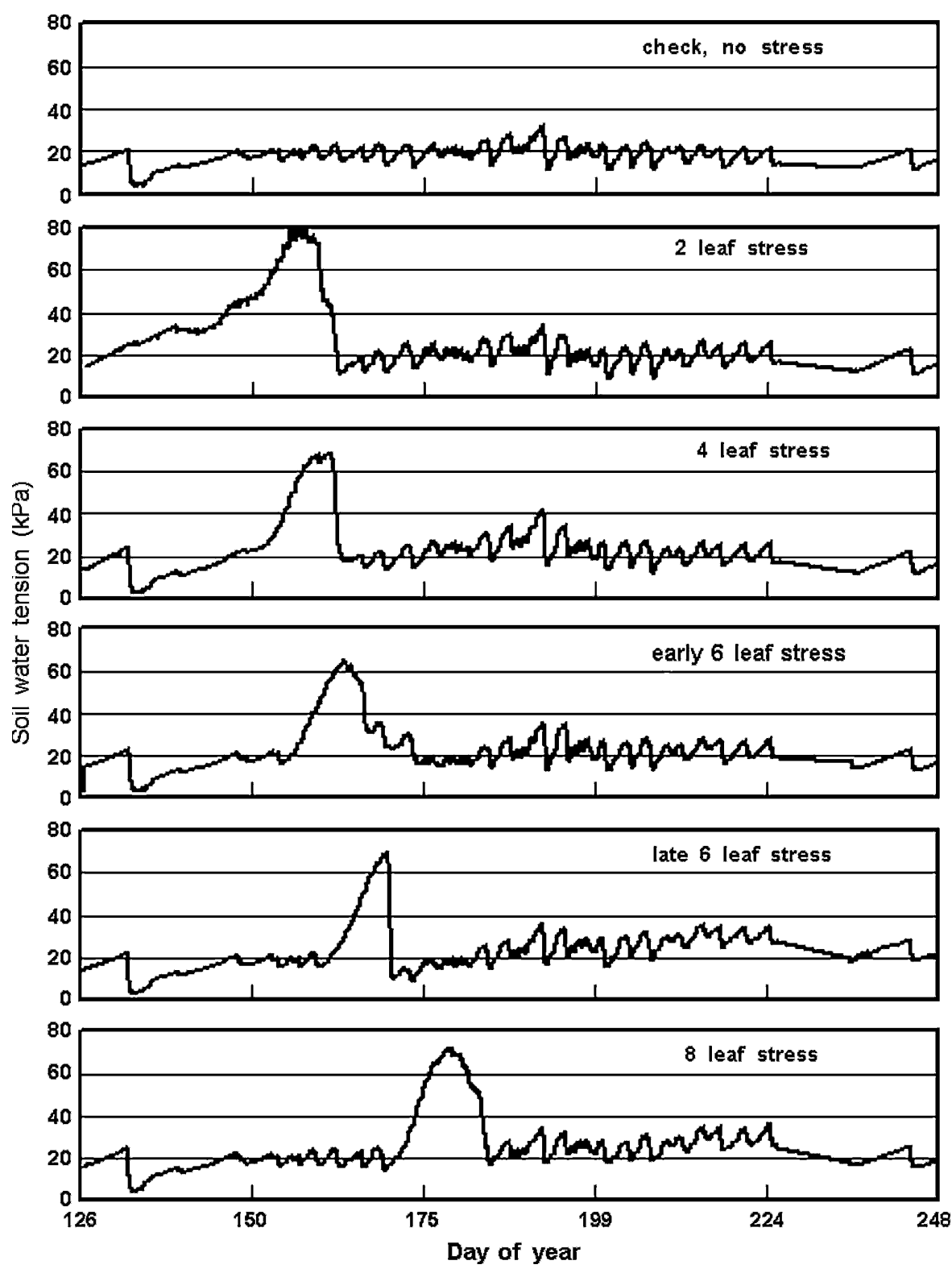

Fig. 2. Soil water tension for onions irrigated at $20 \mathrm{kPa}$ with an automated drip irrigation system and submitted to short-duration water stress in 2004. Data are the average of 20 sensors (four sensors per plot and five replicates).

more than $60 \mathrm{kPa}$, but no more than $80 \mathrm{kPa}$ (Figs. 1-3). The two-leaf stress treatment, which was started on 13 May in 2005, was never achieved because of higher than normal precipitation during the $7 \mathrm{~d}$ immediately before the two-leaf stage ( $44 \mathrm{~mm}$ ) and the $5 \mathrm{~d}$ immediately after the start of the two-leaf stage $(28 \mathrm{~mm})$. The automatic irrigations in 2005 were scheduled to start on 12 May, but because of the wet weather, the first irrigation was on 27 May at the start of the fourleaf stage.

Onion single centeredness and translucent scale. In 2003, water stress at the four-leaf and early six-leaf stages resulted in significantly lower percentages of singlecentered and functionally single-centered bulbs than the control (Table 1). In 2004, water stress did not affect bulb single centeredness. In 2005, water stress at the four-leaf, early six-leaf, and late six-leaf stages resulted in a significantly lower percentage of single-centered and functionally single-centered bulbs than the control (Table 1). In 2005, the reduction in the percentage of single-centered and functionally single-centered bulbs was more pronounced for stress at the four-leaf stage than at the early six-leaf and late sixleaf stages. In 2003 and 2005, stress at the four-leaf stage tended to increase the percentage of bulbs with the larger double centers more than stress at the six-leaf stage. In 2003 and 2005, stress at the fourleaf stage resulted in the highest percentage of bulbs with large double centers greater than stress at the early six-leaf and late six-leaf stages.
Averaged over the 3 years, water stress at the four-leaf, early six-leaf, and late sixleaf stages resulted in a significantly lower percentage of single-centered bulbs than the control. Averaged over the 3 years, water stress at the four-leaf and early sixleaf stages resulted in a significantly lower percentage of functionally single-centered bulbs and a higher percentage of bulbs with large double centers than the control. Averaged over the 3 years, the reduction in the percentage of single-centered and functionally single-centered bulbs was more pronounced for stress at the four-leaf stage than for the early six-leaf and late six-leaf stages.

There was no significant difference between treatments in the percentage of bulbs having translucent scales (Table 1). The percentage of bulbs with translucent scales was low each year, averaging $0.8 \%$ over the 3 years.

Onion yield and grade. Among the treatments and years, total marketable yield was only reduced compared with the control in 2005 with water stress at the eightleaf stage (Table 1). Among the treatments and years, yield of combined jumbo, colossal, and supercolossal bulbs was reduced compared with the control in 2005 with water stress at the four-leaf stage and more severely with water stress at the eight-leaf stage. Averaged over the 3 years, yield of combined jumbo, colossal, and supercolossal bulbs was reduced compared with the control only with water stress at the eight-leaf stage.

Year differences. The percentage of single-centered and functionally single-centered bulbs was highest in 2004 and lowest in 2003 (Table 1). Both average maximum air and $0.10-\mathrm{m}$ soil temperatures during the stress treatments were higher in 2003, lower in 2005, and lowest in 2004 (Table 2). At each stress timing, more days of water stress were required for the SWT to reach $60 \mathrm{kPa}$ in 2005 than in 2004 or 2003 (Figs. 1-3, Table $3)$. The precipitation during the stress treatments in 2005 prolonged the duration of the water stress compared with 2004 and 2003. The longer duration of stress periods in 2005 also resulted in a longer period of SWT above $40 \mathrm{kPa}$ in 2005 than in 2003 and 2004

Total yields varied considerably by site-years, averaging 95.8, 113.8, and 74.1 $\mathrm{Mg} \cdot \mathrm{ha}^{-1}$ in 2003, 2004, and 2005 respectively. Iris yellow spot virus infection reduced onion productivity in 2005; Iris yellow spot virus is becoming a limiting factor in onion production (Gent et al., 2006). Total marketable yield and yield of combined jumbo, colossal, and supercolossal bulbs were highest in 2004 and lowest in 2005 .

\section{Discussion}

The results of the current study show that onion is more susceptible to producing multiple centers when stressed at the 

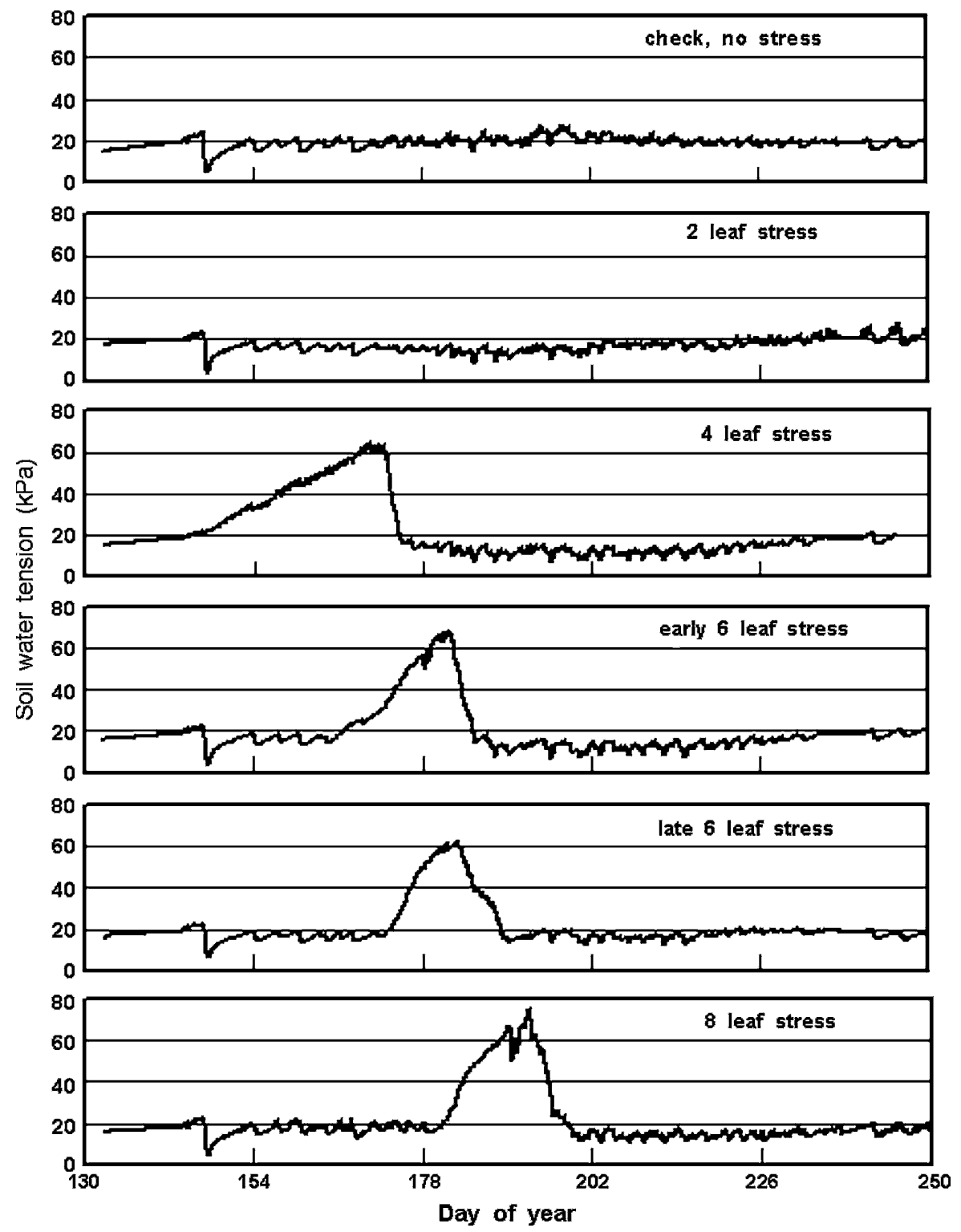

Fig. 3. Soil water tension for onions irrigated at $20 \mathrm{kPa}$ with an automated drip irrigation system and submitted to short-duration water stress in 2005. Data are the average of 20 sensors (four sensors per plot and five replicates).

four-leaf and early six-leaf stages than later at the late six-leaf and eight-leaf stages. During the 3 years, the four-leaf and early six-leaf stages occurred from late May through June. Late May through June is typically when furrow irrigations are interrupted for cultivation and fertilization. Growers typically cultivate twice, with irrigations delayed several days for each cultivation. In 2003, the fourleaf and early six-leaf stresses lasted 8 and $5 \mathrm{~d}$ respectively. The four-leaf and early sixleaf stresses in 2003 resulted in a percentage of functionally single-centered bulbs less than the contract minimum of $75 \%$. The only other stress treatment resulting in a percentage of functionally single-centered bulbs less than the contract minimum was stress beginning at the four-leaf stage in 2005, which resulted from $24 \mathrm{~d}$ of stress on silt loam. The severity of the effect of duration in 2003 and 2004. Also, the longer duration of stress in 2005 might explain the reduction of yield from stress at the four-leaf and eight-leaf stages. The durations of the stress at the four-leaf ( $24 \mathrm{~d})$ and the eightleaf stages (13 d) in 2005 were similar to the durations found by Jones and Johnson (1958), Dragland (1974), and Sorensen and Grevsen (2001) to have reduced onion yield.

Our results are in agreement with Pelter et al. (2004), who found that water stress at the three-leaf stage reduced single centeredness. However, contrary to our results, in the study by Pelter et al. (2004), the reductions in single centeredness with stress at the five-leaf stage were not significantly different from the control. Pelter et al. (2004) found that total yield was reduced by all stress treatments and colossal yield was reduced by stress at the five-, seven-, and nine-leaf stages, contrary to our results. Our results showed yield reductions only in 2005 for total marketable yield from stress at the eight-leaf stage and for yield of combined jumbo, colossal, and supercolossal bulbs from stress at the four-leaf and eight-leaf stages. The yield reductions in the study by Pelter et al. (2004) may be related to the more intense and longer water stress than in our study. The more intense water stress was the result of the consistently higher SWT that the stressed plots were allowed to reach $(70 \mathrm{kPa})$ than in our study, and also the result of their delays in reirrigating at the end of the stress treatments. Several of the stress treatments in the study by Pelter et al. (2004) had SWTs reaching or exceeding $100 \mathrm{kPa}$ for $10 \mathrm{~d}$ or more. The stress levels used in the study by Pelter et al. (2004) are less likely to occur in commercial onion fields.

\section{Conclusion}

Onion single centeredness was reduced by short-duration water stress. Onions were sensitive to the formation of multiple centers with water stress at the four-leaf to late six-leaf stages. Choice of irrigation system and cultivar are important factors in producing single-centered bulbs. Drip irrigation could be more conducive to producing single-centered onions, because the irrigation interruptions necessary for cultivation and fertilization with furrow irrigation are not required. The cultivar used in this study ('Vaquero') has been shown to have among the highest proportion of singlecentered bulbs of commercial onion cultivars tested in this region (Shock et al., 2005). Yield was reduced by short-duration water stress only in one site-year (2005). The yield reductions in 2005 were incited by water stress durations that would not typically occur in commercial onion production. The incidence of translucent scale was low and was not related to early-season water stress. 
Table 1. Response of onion single centeredness, translucent scale, and yield to short-duration water stress.

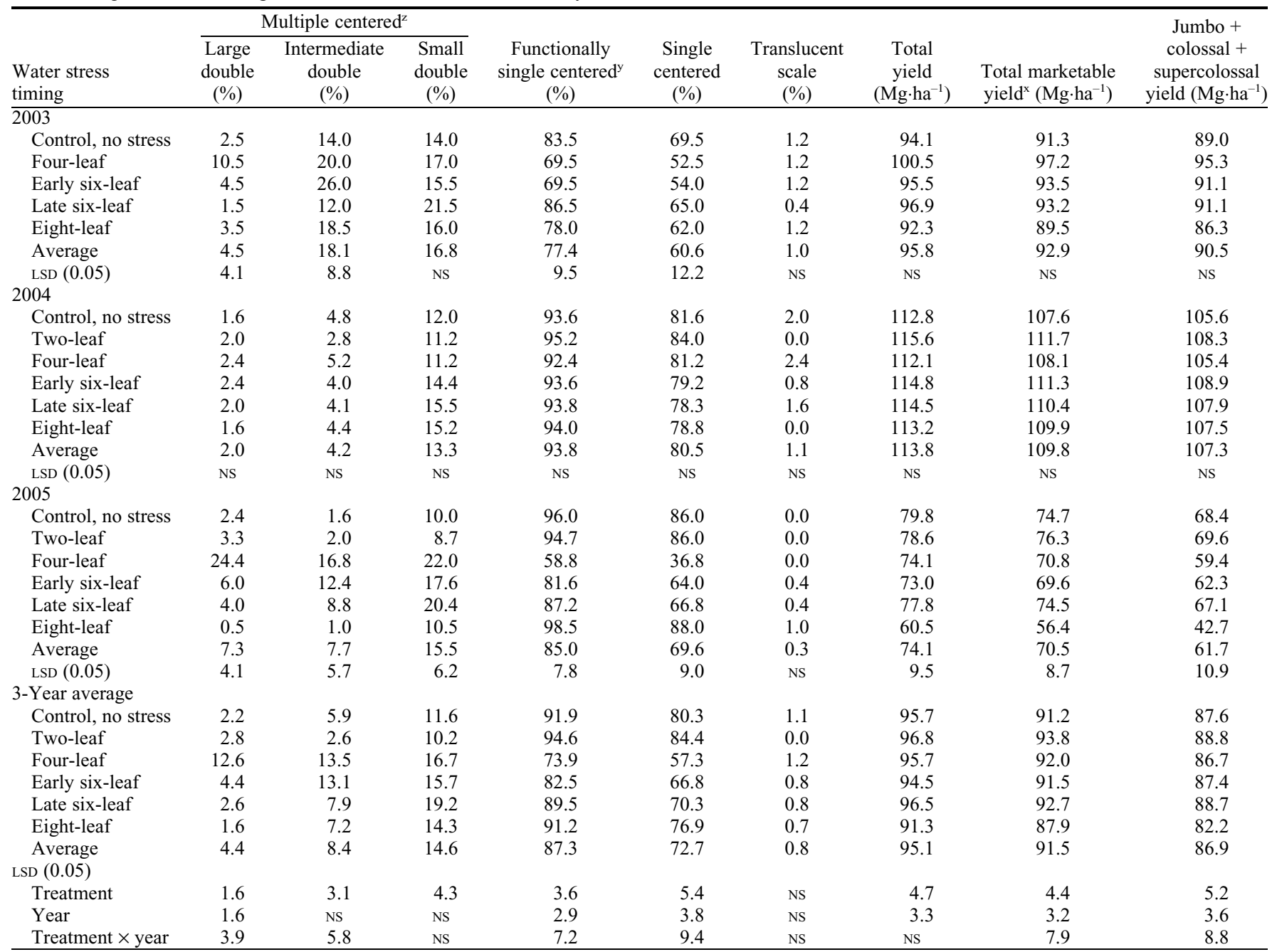

${ }^{2}$ Diameter of the first single ring: small doubles, $<3.8 \mathrm{~cm}$; intermediate doubles, 3.8 to $5.7 \mathrm{~cm}$; and large doubles, $>5.7 \mathrm{~cm}$.

${ }^{\mathrm{y}}$ Functionally single centered $=$ single centered + small double.

${ }^{\mathrm{x}}$ Marketable yield $=$ medium, jumbo, colossal, and supercolossal bulbs.

Table 2. Precipitation, soil temperature (average maximum, $0.10 \mathrm{~m}$ ), and average maximum air temperature during stress treatments

\begin{tabular}{|c|c|c|c|c|c|c|c|c|c|}
\hline \multirow{2}{*}{$\begin{array}{l}\text { Water stress } \\
\text { timing }\end{array}$} & \multicolumn{3}{|c|}{ Precipitation (mm) } & \multicolumn{3}{|c|}{$\begin{array}{c}\text { Average maximum } \\
\text { soil temperature }\left({ }^{\circ} \mathrm{C}\right)\end{array}$} & \multicolumn{3}{|c|}{$\begin{array}{l}\text { Average maximum } \\
\text { air temperature }\left({ }^{\circ} \mathrm{C}\right)\end{array}$} \\
\hline & 2003 & 2004 & 2005 & 2003 & 2004 & 2005 & 2003 & 2004 & 2005 \\
\hline Two-leaf & & 43.2 & & & 16.2 & & & 21.7 & \\
\hline Four-leaf & 0.0 & 14.0 & 23.6 & 21.1 & 17.5 & 19.2 & 29.9 & 23.6 & 24.7 \\
\hline Early six-leaf & 5.8 & 0.5 & 17.3 & 22.4 & 19.6 & 21.4 & 30.6 & 26.7 & 28.4 \\
\hline Late six-leaf & 0.0 & 0.0 & 5.6 & 22.7 & 19.1 & 22.3 & 33.3 & 24.7 & 29.8 \\
\hline Eight-leaf & 0.3 & 6.6 & 9.7 & 22.8 & 21.9 & 22.7 & 34.4 & 30.7 & 30.0 \\
\hline
\end{tabular}

Table 3. Date of stress treatment beginning, duration of stress treatments, and length of time with soil water tension more than $40 \mathrm{kPa}$ during stress treatments.

\begin{tabular}{|c|c|c|c|c|c|c|c|c|c|}
\hline \multirow{2}{*}{$\begin{array}{l}\text { Water stress } \\
\text { timing }\end{array}$} & \multicolumn{3}{|c|}{$\begin{array}{l}\text { Date of stress } \\
\text { beginning }\end{array}$} & \multicolumn{3}{|c|}{ Length of stress (d) } & \multicolumn{3}{|c|}{$\begin{array}{c}\text { Length of time } \\
\text { soil water tension }>40 \mathrm{kPa}(\mathrm{h})\end{array}$} \\
\hline & $\overline{2003}$ & 2004 & 2005 & $\overline{2003}$ & 2004 & 2005 & 2003 & 2004 & 2005 \\
\hline Two-leaf & & May 5 & May 13 & & 28 & $0^{z}$ & & 372 & 0 \\
\hline Four-leaf & June 2 & May 25 & May 27 & 8 & 10 & 24 & 147 & 179 & 392 \\
\hline Early six-leaf & June 16 & June 2 & June 13 & 5 & 9 & 16 & 145 & 177 & 230 \\
\hline Late six-leaf & June 26 & June 11 & June 20 & 6 & 5 & 10 & 91 & 123 & 213 \\
\hline Eight-leaf & July 7 & June 18 & June 28 & 4 & 6 & 13 & 113 & 229 & 290 \\
\hline
\end{tabular}

${ }^{2}$ Soil water tension did not reach the stress threshold at the two-leaf stage in 2005 because of precipitation.

\section{Literature Cited}

Al-Jammal, M.S., T.W. Sammis, S. Ball, and D. Smeal. 2000. Computing the water production function for onion. Agr. Water Mgt. 46:29-41.

Brewster, J.L. 1994. Onions and other vegetable alliums. $\mathrm{CAB}$ International, Wallingford, Oxon, UK.

Bucks, D.A., L.J. Erie, O.F. French, F.S. Nakayama, and W.D. Pew. 1981. Subsurface trickle irrigation management with multiple cropping. Trans. Amer. Soc. Agr. Eng. 24: 1482-1489.

Chung, B. 1989. Irrigation and bulb onion quality. Acta Hort. 247:233-237.

Cramer, C.S. 2006. Onion trait heritability and response from selection. J. Amer. Soc. Hort. Sci. 131:646-650.

de Santa Olalla, F.M., J.A. de Juan Valero, and C.B. Cortes. 1994. Growth and production of onion crop (Allium cepa L.) under different irrigation schedulings. Eur. J. Agron. 3:85-92.

Dragland, S. 1974. Nitrogen and water requirements in onions. Forskning Forsok Landbrucket 26:93-113.

Ells, J.E., A.E. McSay, P.N. Soltanpour, F.C. Schweissing, M.E. Bartolo, and E.G. Kruse. 
1993. Onion irrigation and nitrogen leaching in the Arkansas Valley of Colorado 1990-1991. HortTechnology 3:184-187.

Gamie, A.A., F.A. Ahmed, A.K.I. El-Kafury, and G.H. Abd El-Rehim. 1995. Suitability of $\mathrm{S}_{3}$ progeny of single center Shandaweel 1 onion for bulb production from sets at Sohag. Assiut J. Agr. Sci. 26:73-80.

Gent, D.H., L.J. du Toit, S.F. Fichtner, S.K. Mohan, H.R. Pappu, and H.F. Schwarz. 2006. Iris yellow spot virus: An emerging threat to onion bulb and seed production. Plant Dis. 90:1468-1480.

Hegde, D.M. 1986. Effect of irrigation regimes on dry matter production, yield, nutrient uptake and water use of onion. Indian J. Agron. 31:343-348

Jones, S.T. and W.A. Johnson. 1958. Effect of irrigation at different minimum levels of soil moisture and of imposed drought on yield of onions and potatoes. J. Amer. Soc. Hort. Sci. $71: 440-445$

Kadayifci, A., G.I. Tuylu, Y. Ucar, and B. Cakmak. 2005. Crop water use of onion (Allium cepa L.) in Turkey. Agr. Water Mgt. 72:59-68.

Koriem, S.O., M.M.A. El-Koliey, and M.F. Wahba. 1994. Onion bulb production from
"Shandwell 1" sets as affected by soil moisture stress. Assiut J. Agr. Sci. 25:185-193.

Nassar, A. and E.A. Waly. 1977. Yield and grade of onions as affected by irrigation frequency and stage of maturity. Ann. Agr. Sci. Moshtohor 8:129-136.

Pelter, G.Q., R. Mittelstadt, B.G. Leib, and C.A. Redula. 2004. Effects of water stress at specific growth stages on onion bulb yield and quality. Agr. Water Mgt. 68:107-115.

Rana, D.S. and R.P. Sharma. 1994. Effect of irrigation regime and nitrogen fertilization on bulb yield and water use of onion (Allium cepa). Indian J. Agr. Sci. 64:223-226.

Shock, C.C. 2003. Soil water potential measurement by granular matrix sensors, p. 899-903. In: B.A. Stewart and T.A. Howell (eds.). The encyclopedia of water science. Marcel Dekker, New York.

Shock, C.C., J.M. Barnum, and M. Seddigh. 1998a. Calibration of watermark soil moisture sensors for irrigation management, p. 139-146. In Proceedings of the International Irrigation Show, Irrigation Association, San Diego, CA.

Shock, C.C., E.B.G. Feibert, and L.D. Saunders 1998b. Onion yield and quality affected by soil water potential as irrigation threshold. HortScience 33:188-191.
Shock, C.C., E.B.G. Feibert, and L.D. Saunders. 2000a. Irrigation criteria for drip-irrigated onions. HortScience 35:63-66.

Shock, C.C., E.B.G. Feibert, and L.D. Saunders. 2000b. Onion storage decomposition unaffected by late-season irrigation reduction. HortTechnology 10:176-178.

Shock, C.C., E.B.G. Feibert, and L.D. Saunders. 2005. Single-centered and supercolossal bulbs from yellow onion cultivars. HortTechnology 15:399-408.

Sorensen, J.N. and K. Grevsen. 2001. Sprouting in bulb onions (Allium cepa L.) as influenced by nitrogen and water stress. J. Hort. Sci. Biotechnol. 76:501-506.

Van Eeden, F.J. and J. Myburgh. 1971. Irrigation trials with onions. Agroplantae 3:57-62.

Wall, M.M., A. Mohammad, and J.N. Corgan. 1996. Heritability estimates and response to selection for the pungency and single center traits in onion. Euphytica 87:133139.

Werner, J.L. and C.M. Harris. 1965. Factors influencing the incidence of translucent scale of stored onion bulbs. J. Amer. Soc. Hort. Sci. 87:341-354. 